\title{
DETERMINANTS OF HERBICIDE UTILIZATION IN STRIGA HERMONTHICA CONTROL AMONG MAIZE FARMING HOUSEHOLDS IN GIWA LOCAL GOVERNMENT AREA OF KADUNA STATE, NIGERIA
}

\author{
Oyakhilomen Oyinbo, Mamman Kwagman Saleh, Grace Zibah Rekwot, Researchers \\ Ahmadu Bello University, Nigeria \\ E-mail: ooyinbo@abu.edu.ng, saintoyas@yahoo.com
}

\begin{abstract}
The study was carried out to determine the socioeconomic and institutional factors that influence the utilization of herbicide for the control of Striga in maize production. Structured questionnaire with the aid of personal interview was used to collect data from a sample size of eighty respondents selected purposively from Shika, Giwa, Yakawada and Galadimawa villages of the study area. Data collected were analyzed using descriptive statistics and OLS regression analysis. The result of the analysis showed that household size $(P<0.1)$, household income $(P<0.05)$ and educational level $(P<0.01)$ are the socioeconomic variables significant in influencing herbicide utilization by maize farming households while membership of association $(P<0.01)$ and extension contact $(P<0.01)$ are the institutional variables significant in influencing herbicide utilization by maize farming households in the study area. The high significance of membership of association and extension contact implies that farmers associations and extension agents are very relevant in influencing farmers decision on weed control techniques through information dissemination about the techniques of weed control. It is therefore recommended that farmers associations and extension agents should be fully involved in disseminating improved techniques of weed control as they have been found to be very relevant in farmers utilization of herbicide as a technique of striga control.
\end{abstract}

\section{KEY WORDS}

Striga; Herbicide; Maize; Farming; Weed.

Striga is a crop parasite that is considered to be one of the biggest constraints to agriculture in sub-Saharan Africa (IITA, 2012). Striga hermonthica is a parasitic weed that attacks maize, sorghum and other staple cereal crops and has long been considered one of the greatest biotic constraints to cereal production in Africa (Kamara et al., 2008). The parasite infests some $40 \%$ of the cereal-producing areas of sub-sahara Africa resulting to crop losses estimated at US $\$ 7$ billion annually, affecting livelihoods of approximately 300 million people (Ejeta, 2007). Striga has its greatest impact in low-input subsistence farming systems and farmers have attributed increasing striga damage to continuous cropping of host crops, poor soil fertility, lack of capital, and infestation of previously uninfested fields by striga seeds (Kureh et al., 2003; Schulz et al., 2003; Emechebe et al., 2004).

Economic analysis has shown that the use of Striga tolerant maize and legume trap crops grown in rotation with maize can provide better returns than continuous maize. However, if maize prices increase relative to legumes and fertilizer prices decrease, continuous maize production can become more profitable (Kureh et al., 2006). Striga produces several seeds, and during tillage the seeds are incorporated into the soil where they can be dormant for many years. Over time they are spread to new areas by human beings through the tools used for land preparation and weeding (Oswald, 2005). The seeds are also spread by animals moving from one field to another for grazing purposes (Hearne, 2009). Striga pandemic in sub-sahara Africa has increased due to non advocacy of nutrient replenishment of the soils as a result of mono-cropping, a factor for increased infestation of the weed in size and severity (Woomer, 2004). Poverty level of small scale farmers has enhanced the spread of striga through sharing of seeds collected from the previous crop harvest (Areta et al., 2011).

Past research efforts have identified several effective control technologies (Swarbrick et al., 2009; Kaewchumnong and Price, 2008; Parker and Riches 1993; Sauerborn, 1999; Schulz et al., 2003; Carsky et al., 2000; Mumera and Below 1993; Debra et al., 1998; Kim et 
al., 1997). These include using resistant/tolerant varieties, sowing clean seeds that are not contaminated with Striga seeds, rotating cereal hosts with trap crops that induce abortive germination of Striga seeds, applying organic and inorganic soil amendments such as fertilizer or manure, fumigating soil with ethylene, hoeing and hand-pulling of emerged Striga, applying post-emergence herbicides, and using biological control agents. Despite the notable advances in Striga weed control technology over time, the devastating effect of the weed continues to be a major cause of low agricultural production (Atera et al., 2011). This is an indication of poor linkage between research institutions and agricultural extension which is a bottleneck to research findings to benefit farmers.

It is worth noting that despite the efforts of several researchers in dealing with the menace of striga infestation, there exists a gap in research with respect to the factors influencing the utilization of striga control measures by farmers. Therefore, this research was carried out to fill the gap in research by providing empirical information on the socioeconomic and institutional factors influencing the utilization of herbicide in the control of striga using a case study of maize farmers in Giwa local government area of Kaduna state.

\section{MATERIALS AND METHODS}

Description of Study Area. The study was conducted in Giwa Local Government Area of Kaduna State, Nigeria. Giwa Local Government Area of Kaduna State is located in the plain of the Northern part of Kaduna State. It lies between latitude $12.20^{\circ} \mathrm{N}$ to $12.52^{\circ} \mathrm{N}$ and longitude $7.0^{\circ} \mathrm{E}$ to $7.5^{\circ} \mathrm{E}$. The local government had an estimated population of 286,427 people in 2006(NPC, 2006) with a projected population of 332, 255 people in 2011 at a population growth rate of 3.2 per cent. The local government area is blessed with floodplains popularly known as Fadama lands. These floodplains are characterized by availability and accessibility to both open surface and under ground water. The major crops grown during the dry season are tomatoes, pepper, onions, wheat, lettuce, carrot, garden egg plant, maize, amaranthus and sugarcane. The major source of livelihood in this area is agriculture and the bulk of agricultural production is undertaken by small farmers of which women are included.

Sampling Procedure and Data Collection. A two stage sampling technique was employed to select the respondents of this study. The first stage involved a purposive selection of four villages namely; Shika, Giwa, Yakawada and Galadimawa. These villages were selected purposively based on their high intensity in maize farming. The second stage involved a purposive selection of twenty maize farmers who utilized herbicide in the $2010 / 2011$ cropping season from each of the four villages to give a sample size of eighty maize farmers. Primary data were employed in this study and the data were collected using structured questionnaires with the aid of personal interview. The primary data collected included the socioeconomic characteristics of the maize farmers, inputs used in maize production and the output of maize production.

Analytical Procedure. The Ordinary Least Squares (OLS) multiple regression estimation was employed to determine the socioeconomic and institutional factors that influence herbicide utilization in Striga hermonthica control. The model was specified as:

$$
Y=f\left(X_{1}, X_{2}, X_{3}, X_{4}, X_{5}, X_{6}, X_{7}, X_{8}, X_{9}, X_{10}\right)
$$

The explicit form of the model was given as:

$$
Y=\delta_{0}+\delta_{1} X_{1}+\delta_{2} X_{2}+\delta_{3} X_{3}+\ldots \ldots \ldots \ldots \ldots+\delta_{10} X_{10}+\varepsilon
$$

Where:

$Y=$ Quantity of herbicide utilized (litre)

$X_{1}=$ Age (years)

$X_{2}=$ Marital status $($ Married $=1$, Single $=0$ )

$X_{3}=$ Household size(number of household members)

$X_{4}=$ Educational level(years of formal schooling) 
$X_{5}=$ Household income (naira)

$X_{6}=$ Farm size(hectare)

$X_{7}=$ Membership of associations

$X_{8}=$ Access to credit

$X_{9}=$ Extension contacts(number of extension visits)

$X_{10}=$ Farming experience (years)

$\delta_{0}=$ Constant term

$\varepsilon=$ Error term

$\delta_{1}-\delta_{10}=$ Estimated coefficients of the independent variables.

Eviews 7.2 was used to carry out the multiple regression analysis of the factors that influenced herbicide utilization in Striga hermonthica control.

\section{RESULT AND DISCUSSION}

Factors Influencing the Utilization of Herbicide for Striga Control. The result of the regression analysis showing the factors that influence that influenced herbicide utilization by maize farmers is presented in Table 1 . The $R$ Square of 0.84 indicates that 84 per cent of the variation in the herbicide utilization by the maize farmers was explained by the independent variables included in the model. The F-statistic of 17.311 was significant at 1 per cent probability level which implies that the model gave a good fit for the analysis.

Table 1. Factors influencing the utilization of herbicide for striga control

\begin{tabular}{|c|c|c|c|}
\hline Variable & Coefficient & Standard error & tratio \\
\hline Constant & 5.769 & 1.688 & 3.418 \\
\hline Age & -2.774 & 1.910 & -1.452 \\
\hline Marital status & 3.116 & 2.499 & 1.247 \\
\hline Household size & -2.975 & 1.604 & $-1.855^{*}$ \\
\hline Educational level & 4.311 & 1.346 & $3.204^{\star \star x}$ \\
\hline Household income & 6.256 & 3.042 & $2.056^{\star \star}$ \\
\hline Farm size & -3.847 & 2.385 & -1.613 \\
\hline M. associations & 5.366 & 1.498 & $3.581^{\star \star x}$ \\
\hline A. credit & 2.759 & 1.886 & 1.463 \\
\hline Extension contact & 5.824 & 1.913 & $3.044^{\star \star x}$ \\
\hline Farming experience & -2.646 & 1.718 & -1.540 \\
\hline R-Square $\left(R^{2}\right)$ & 0.890 & - & - \\
\hline Adjusted R-Square $\left(\bar{R}^{2}\right)$ & 0.840 & - & - \\
\hline F-Statistic & 17.311 & - & 4.322 \\
\hline
\end{tabular}

NB: ${ }^{* *} p<0.01^{* *} P<0.05{ }^{*} P<0.1$

The result in the table indicates that household income, educational level, membership of farmers associations and extension contact were significant in influencing the utilization of herbicides by the maize farmers while age, marital status, household size, farm size, access to credit and farming experience were found to be in significant.

Age: this variable was found to be negatively related to herbicide utilization in striga control but was not significant at the three probability levels(1\%, 5\% and $10 \%)$.

Marital status: this was found to be insignificant in influencing utilization of herbicide for the control of striga in the study area.

Household size: this variable was found to be negative and significant in influencing herbicide utilization for the control of striga. This implies that a unit increase of this variable will decreases herbicide utilization by a magnitude of 2.975 and this inverse relationship could be attributed to the increase in the farmers household expenditure resulting from an increase in household size of the farmers leading to the reduction of the relative income of the farmers and consequently, available income for purchase of herbicide.

Educational level: this variable was found to be positively related to herbicide utilization in striga control and significant at 0.001 probability level. This implies that an increase in the 
educational level of the farmers will increase the utilization of herbicides for striga control by farmers.

Household income: this was found to be positive and significant in determining herbicide utilization in striga control such that a unit increase in household income will increase the utilization of herbicide by a magnitude of 6.256 . This is not unconnected to the theory underpinning income as a major determinant of demand for commodities.

Farm size: found to be negatively related to herbicide utilization in the control of striga but not significant.

Membership of associations: was found to be positive and significant in influencing the utilization of herbicide in the control of striga. A unit increase of this variable will increase the utilization of herbicide by a magnitude of 5.366 and this could be attributed to the vital role of farmers associations as avenues for farmers to get information about farming practices and access farming inputs at a subsidized rate.

Access to credit: this was expected to be significant in influencing the utilization of herbicides for the control of striga but was found to be insignificant. This could be attributed to the inability of most of the farmers to access adequate amount of credit to enable them purchase all the necessary farming inputs.

Extension contact: this variable was found to be significant and positively related to herbicide utilization in the control of striga. This implies that he higher the number of extension contacts by the maize farmers, the higher the utilization of herbicide in the control of striga and this could be attributed to the dissemination of information on striga control by extension agents during extension visits. This finding is in line with Umar et al.(2009) who observed that higher extension contacts will increase the adoption of improved farm production technologies.

Farming experience: was found to be positively related to herbicide utilization but not significant.

\section{CONCLUSION AND RECOMMENDATION}

This study has provided empirical information on the factors influencing herbicide utilization in the control of striga by maize farming households in the study area using primary data elicited from the maize farmers and analysed using multiple regression analysis. Household income and education level were the socioeconomic factors that influenced the utilization of herbicide by maize farmers and membership of associations and extension contacts were the institutional factors that influenced the utilization of herbicide by the maize farmers. Based on these findings, it is recommended that farmers associations and extension agents should be fully involved in disseminating improved techniques of weed control as they have been found to be very relevant in influencing farmers utilization of herbicide as a technique of striga control.

\section{REFERENCES}

[1] Atera, E.A., Itoh, k. and Onyango, J.C. (2011). Evaluation of ecologies and severity of Striga weed on rice in sub-Saharan Africa. Agriculture and Biology Journal of North America, Vol. 2, No.5, pp. 752-760.

[2] Carsky, R.J., Berner, D.K., Oyewole, B.D., Dashiell, K. and Schulz, S. (2000). Reduction of Striga hermonthica parasitism on maize using soybean rotation. International Journal of Pest Management, Vol. 46, No. 2, pp. 115-120.

[3] Debra, S.K., Defoer, T. and Bengaly, M. (1998). Integrating farmers' knowledge, attitude and practice in the development of sustainable Striga control interventions in southern Mali. Netherlands Journal of Agricultural Science, 46:65-75.

[4] Ejeta, G. (2007). The Striga scourge in Africa: a growing pandemic. In: Ejeta G. and Gressel J. (eds). Integrating New Technologies for Striga Control: Towards ending the witch-hunt. World Scientific Publishing Co. Pte Ltd, 5 Tol Tuck Link, Singapore, 316. 
[5] Emechebe, A.M., Ellis-Jones, J., Schulz, S., Chikoye, D., Douthwaite, B., Kureh, I., Tarawali, G., Hussaini, A.M., Kormawa, P. and Sanni, A. (2004). Farmers' perception of the Striga problem and its control in northern Nigeria. Experimental Agriculture, Vol. 40, No. 2, pp. 215-232.

[6] Hearne, S.J. (2009). Control - the Striga conundrum. Pest Management Science, Vol. 65 , No. 5, pp. 603-614.

[7] International Institute for Tropical Agriculture, (2012). Saving Africa's maize and cowpea from the violet vampire. IITA News.

[8] Kaewchumnong, K. and Price, A.H. (2008). A study on the susceptibility of rice cultivars to Striga hermonthica and mapping of Striga tolerance quantitative trait loci in rice. New Phytol. Vol. 180, No.1, pp. 206-216.

[9] Kamara, A.Y., Ellis-Jones, J., Amaza, P., Omoigui, L.O., Helsen., J., Dugje, I. Y., Kamai, N., Menkir, A. and White, R.. W.(2008). A Participatory Approach to Increasing Productivity of Maize through Striga Hermonthica Control in Northeast Nigeria, Experimental Agriculture, Vol. 44, No. 3, pp.349-364

[10] Kim, S.K., Adetimirin, V.O. and Akintunde, A.Y. (1997). Nitrogen effects on Striga hermonthica infestation, grain yield, and agronomic traits of tolerant and susceptible maize hybrids. Crop Science, Vol. 37, No. 3, pp. 711-716.

[11] Kureh, I., Hussaini, A.M., Chikoye, D., Emechebe, A.M., Kormawa, P., Schulz, S., Tarawali, G., Franke, L.C., and Ellis-Jones, J. (2003). Promoting integrated Striga management practices in maize in northern Nigeria. Pages 1023-1028 in The 2003 Brighton Crop Protection Conference-weeds. Proceedings of an International Conference, 17-20 Nov 2003, Brighton. British Crop Protection Council, Farnham, Surrey, UK.

[12] Mumera, L.M. and Below, F.E. (1993). Role of nitrogen in resistance to Striga parasitism of maize. Crop Science, Vol. 33, No. 4, pp.758-763.

[13] National Population Commission, (2006). Official Census Figure, NPC, Abuja, Nigeria.

[14] Oswald, A. (2005). Striga control-technologies and their dissemination. Crop Protection, Vol. 24, No. 4, pp. 333-342.

[15] Parker, C. and Riches, C.R. (1993). Parasitic weeds of the world: biology and control. CAB International, Wallingford, UK.

[16] Sauerborn, J. (1999). Striga biology versus control. Pages 133-144 in Advances in parasitic weed control at on-farm level, edited by J. Kroschel, H. Mercer-Quarshie, and J. Sauerborn. Vol. 1. Joint action to control Striga in Africa. Margraf Verlag, Weikersheim, Germany.

[17] Schulz, S., Hussaini, M.A., Kling, J.G., Berner, D.K. and Ikie, F.O. (2003). Evaluation of integrated Striga hermonthica control technologies under farmer management. Experimental Agriculture, Vol. 39, No. 1, pp. 99-108.

[18] Swarbrick, P.J., Scholes, J.D., Press, M.C. and Slate, J. (2009). A major QTL for resistance of rice to the parasitic plant Striga hermonthica is not dependent on genetic background. Pest Management Science, Vol. 65, No. 5, pp. 528-532.

[19] Woomer, P. (2004). New approaches to controlling Striga infestation: AATF Striga Management project. Farmers Journal, Vol. 1, pp. 1-3. 